\title{
STRATEGI KESANTUNAN TINDAK TUTUR DIREKTIF PEMILIK BISNIS JASA WEDDING ORGANIZER DALAM PESAN WHATSAPP
}

\author{
Fathiyyah Sekar Widiasri \\ Universitas Padjadjaran \\ fathiyyah15001@mail.unpad.ac.id
}

\begin{abstract}
Abstrak
Selain prinsip kerja sama, kesantunan berbahasa merupakan hal yang diperlukan dalam suatu tindak komunikasi. Kesantunan berbahasa ini dapat dilihat dari strategi kesantunan yang digunakan oleh penutur saat berinteraksi dengan lawan tutur. Penelitian ini bertujuan untuk mendeskripsikan strategi kesantunan pada pesan antara pemilik bisnis dengan klien dan rekan kerjanya. Teori yang digunakan adalah teori strategi kesantunan menurut Brown dan Levinson (1987). Penelitian ini menggunakan metode deskriptif kualitatif dengan pendekatan pragmatis. Sumber data pada penelitian ini adalah pesan yang dikirim melalui WhatsApp antara pemilik bisnis dengan klien dan rekan kerjanya di dalam bisnis jasa Wedding Organizer (WO). Tahap penelitian yang digunakan dalam penelitian ini terdiri dari tiga tahapan, yaitu tahap penyediaan data, tahap analisis data, dan tahap penyajian hasil analisis data. Hasil dari penelitian ini menunjukkan bahwa ada tiga strategi kesantunan berbahasa yang digunakan oleh penutur yang terbagi menjadi: 1) strategi kesantunan positif sebanyak 15 data; 2) strategi kesantunan negatif sebanyak 5 data; dan 3) strategi tidak langsung sebanyak 5 data.
\end{abstract}

Kata kunci: pragmatik, strategi kesantunan, bisnis jasa, wedding organizer

\begin{abstract}
Language politeness is necessary thing in an act of communication besides the cooperative principles. This language politeness can be seen from the politeness strategies used by speakers when interacting with interlocutors. This research aims to describe the politeness strategies on messages between business owner and his clients and colleagues. The theory used is the politeness strategy theory according to Brown and Levinson (1987). This reserach uses a qualitative descriptive method with a pragmatic approach. Sources of data in this research are messages sent via WhatsApp between business owner and his clients and colleagues in the Wedding Organizer (WO) service business. The research stage used in this research consists of three stages, there are the stage of providing data, the stage of data analysis, and the stage of presenting the results of data analysis. The result of this research shows that there are three politeness strategies used by speakers which are divided into: 1) 15 data of positive politeness strategy; 2) 5 data of negative politeness strategy; and 3) 5 data of off-record politeness strategy.
\end{abstract}

Keywords: pragmatic, politeness strategies, service business, wedding organizer

\section{PENDAHULUAN}

Bahasa sebagai alat komunikasi menjadi peran yang sangat penting dalam kehidupan manusia. Bahasa digunakan manusia untuk berinteraksi dengan manusia lainnya dalam seluruh kegiatannya. Kegiatan yang dimaksud adalah segala aktivitas keseharian manusia dari bangun hingga tidur kembali, misalnya saat bercengkrama dengan keluarga, bersekolah, bermain, dan bekerja. Peran bahasa dapat dikatakan 
sangat krusial khususnya dalam kegiatan bekerja dimana baik atau tidaknya cara berbahasa dan berkomunikasi seseorang dapat berdampak bagi pekerjannya. Misalnya, seorang karyawan yang bahasanya buruk atau tidak sopan dapat menimbulkan kesan negatif dan dianggap tidak menghargai rekan kerjanya, sehingga mengakibatkan orang tersebut tidak dipercaya bahkan, lebih jauh lagi, kemungkinan dipecat atau diberhentikan akan semakin besar.

Contoh di atas juga dapat terjadi di dalam sebuah bisnis Wedding Organizer (WO). Wedding Organizer (WO) merupakan sebuah bisnis jasa dimana tindak komunikasi yang digunakan di dalamnya dapat berupa komunikasi formal atau informal dengan bergantung pada konteks yang melatarbelakangi suatu tindak komunikasi tersebut. Hal ini sangat berkaitan dengan bidang kajian linguistik yaitu pragmatik. Berdasarkan kajian pragmatik, konteks dapat berpengaruh terhadap apa yang dikatakan dan bagaimana cara pendengar dapat menyimpulkan tentang apa yang dituturkan agar dapat sampai pada suatu interpretasi makna yang dimaksudkan oleh penutur (Adani, 2017: 83). Penutur yang tidak memerhatikan situasi tuturan akan menyebabkan kesalahpahaman lawan tutur dan dapat menimbulkan hubungan yang tidak harmonis antar penutur dimana hal tersebut adalah hal yang sangat dihindari di dalam sebuah bisnis jasa Wedding Organizer (WO). Oleh karena itu, penutur harus memperhatikan kaidah atau aturan demi terjalinnya interaksi yang baik.

Kaidah atau aturan tersebut adalah dengan cara menyadari aspek ekstralingual, yaitu situasi dan kondisi penutur pada saat berinteraksi. Hal ini diungkapkan oleh Hymnes (dalam Santoso, 2005: 3), menurutnya, aspek-aspek ekstralingual yang perlu diketahui tersebut, antara lain adalah siapa saja yang terlibat dalam interaksi, bagaimana hubungan dan jarak sosial di antara mereka atau status relatif di antara mereka, latar terjadinya peristiwa tutur, tujuan yang ingin dicapai, saluran yang digunakan, cara pengungkapan suatu maksud, dan lain sebagainya. Hal ini menjadi sangat penting karena akan menentukan dan mengatur penutur untuk dapat menyampaikan informasi atau gagasan dengan jelas dan tidak terjadi kesalahpahaman dalam berkomunikasi. Bagaimana penutur memperlakukan lawan tutur dan menjaga hubungan komunikasi yang baik dengan lawan tutur adalah salah satu penentu kelancaran dalam berkomunikasi yang termasuk ke dalam bagian dari kesantunan.

Menurut Mulatsih (2014: 214), secara umum kesantunan didefinisikan sebagai kepatutan sosial, yaitu tindakan dimana seseorang menunjukkan tingkah laku yang teratur dan menghargai orang lain sesuai dengan norma yang berlaku di masyarakat. Untuk menjadi santun, seseorang harus mematuhi aturan yang berlaku dalam setiap ikatan sosial (Fraser, B., \& Nolen, 1981: 96). Kesantunan adalah fenomena universal dalam pemakaian bahasa pada konteks sosial sehingga kesantunan menjadi hal yang fundamental dalam kajian pragmatik. Leech (1982: 132) mengungkapkan bahwa dalam berkomunikasi, diperlukan aturan-aturan lain selain aturan kerja sama, yaitu aturan kesantunan berbahasa atau prinsip kesantunan. Aturan kesantunan yang dimaksud adalah aturan dalam menjaga hubungan interaksional antar penutur agar tetap terjaga hubungan personal yang saling menghormati, tidak merugikan dan tidak mengancam Face 'muka' satu sama lain. 
Terdapat dua jenis Face 'muka' menurut Brown dan Levinson (1987: 62), yaitu positive face 'muka positif' dan negative face 'muka negatif'. Muka positif adalah keinginan setiap manusia untuk disetujui, dimengerti, diterima, dan sebagainya, sedangkan muka negatif adalah keinginan setiap individu dewasa agar tindakannya tidak dihalangi oleh orang lain.

Menurut Brown dan Levinson (dalam Syahrin, 2008) ada empat strategi kesantunan atau pola perilaku umum yang dapat diaplikasikan penutur yaitu (1) Bald-on Record Strategy (tanpa strategi); (2) Positive politeness strategy (strategi kesantunan positif / keakraban); (3) Negative politeness strategy (strategi kesantunan negatif /formal); (4) Off-record politeness strategy (strategi tidak langsung atau tersamar). Masing-masing strategi kesantunan tersebut akan dijelaskan di bawah ini:

\section{Bald-on Record Strategy (Strategi Terus Terang/ Tanpa Strategi)}

Strategi ini sejalan dengan prinsip efisiensi dalam komunikasi yang dituangkan dalam maksim Grice (Grice 1975, dalam Brown dan Levinson 1987: 94). Penutur yang menggunakan strategi ini tidak melakukan usaha apapun untuk meminimalisasi ancaman bagi muka lawan tutur atau untuk mengurangi akibat dari tindakan yang mengancam muka (FTA). Akibatnya, lawan tutur akan merasa terkejut, malu, dan tidak nyaman. Strategi ini diwujudkan dalam kalimat imperatif langsung yang biasanya digunakan oleh penutur dan lawan tutur yang telah saling mengenal dengan baik, misalnya antara teman sebaya atau anggota keluarga. Contoh penggunaan strategi ini dapat dilihat dalam (1) mengekspresikan keadaan darurat: "tolong hubungi polisi!"; (2) tindakan yang berorientasi pada penugasan/instruksi: "ambilkan buku saya"; (3) menarik perhatian di tengah suatu aktifitas: "tutup matamu!".

\section{Positive Politeness Strategy (Strategi Kesantunan Positif / Keakraban)}

Strategi ini digunakan untuk menunjukkan keakraban kepada lawan tutur yang tidak memiliki hubungan dekat dengan penutur. Untuk memudahkan interaksinya, penutur mencoba memberi kesan senasib dan seolah-olah mempunyai keinginan yang sama dengan lawan tutur, hal ini ditujukan langsung kepada muka positif lawan tutur supaya keinginan penutur dianggap sebagai keinginan bersama antara penutur dengan lawan tutur. Penutur menunjukkan bahwa dia ingin lebih akrab dengan lawan tutur dan berusaha meminimalisasi jarak dengan lawan tutur dengan cara mengungkapkan perhatian dan persahabatan. Dengan kata lain, strategi ini dapat berfungsi sebagai pelancar hubungan sosial dengan orang lain karena penutur meminimalisasi FTA. Strategi kesantunan positif direalisasikan dengan lima belas cara atau tindakan, yaitu: a) Memusatkan perhatian pada diri lawan tutur; b) Memberi perhatian lebih, memberikan pengakuan atau simpati kepada lawan tutur; c) Mengintensifkan perhatian kepada lawan tutur; d) Menggunakan penanda keakraban kelompok; e) Menemukan kesepakatan; f) Menghindarkan konflik; g) Menyamakan anggapan menjadi pendapat umum; h) Berkelakar; i) Menambahkan atau menyetujui pendapat lawan tutur; j) Menawarkan bantuan atau janji; k) Bersikap optimis; 1) Melibatkan penutur dan lawan tutur dalam kegiatan; m) Memberikan atau menanyakan alasan tertentu; n) Mengasumsikan atau menampilkan kesamaan tindakan; dan o) Memberikan hadiah 


\section{Negative Politeness Strategy (Strategi Kesantunan Negatif / Formal)}

Tindakan yang dilakukan pada strategi ini bertujuan untuk menebus muka negatif lawan tutur dan keinginan penutur untuk terbebas dari beban dengan maksud agar tindakan dan maksudnya tidak terganggu dan tidak terkendala. Tindakan ini adalah dasar dari perilaku menghargai lawan tutur yang juga terdapat pada strategi kesantunan positif. Hal yang menjadi pembeda adalah strategi ini lebih spesifik dan lebih terfokus karena penutur menampilkan fungsi-fungsi penunjang untuk meminimalisasi beban tertentu sebagai sesuatu yang tidak bisa dihindarkan oleh lawan tutur. Fokus utama penggunaan strategi ini adalah dengan mengasumsikan bahwa penutur kemungkinan besar memberikan beban atau gangguan kepada lawan tutur karena telah memasuki daerah lawan tutur. Dengan kata lain, terdapat jarak sosial tertentu atau hambatan tertentu antara penutur dengan lawan tutur. Strategi kesantunan ini direalisasikan dengan sepuluh cara atau tindakan, yaitu: a) Menyatakan secara tidak langsung; b) Mengajukan pertanyaan atau mengelak; c) Bersikap pesimis; d) Mengecilkan beban permintaan; e) Merendahkan diri; f) Meminta maaf; g) Personalisasi penutur dan lawan tutur; h) Menempatkan tindakan mengancam muka sebagai aturan yang berlaku umum; i) Nominalisasi; dan j) Menyatakan secara jelas bahwa tindakan lawan tutur sangat berharga bagi penutur.

\section{Off-record Politeness Strategy (Strategi Tidak Langsung / Tersamar)}

Strategi ini direalisasikan dengan cara tersamar dan tidak menggambarkan maksud komunikatif yang jelas. Penutur membawa dirinya keluar dari tindakan dengan membiarkan lawan tutur menginterpretasikan sendiri tindakannya. Strategi ini digunakan jika penutur ingin melakukan tindakan mengancam muka namun tidak ingin bertanggung jawab atas tindakan tersebut. Contoh tuturan dari tindakan ini adalah: "Selamat siang, mau mengingatkan nanti meeting jam 2 di hotel gunung putri $y a^{\prime \prime}$. Pada tuturan tersebut, penutur secara tidak langsung melakukan tindakan permohonan atau permintaan kepada lawan tutur.

Strategi kesantunan dapat digunakan pada semua jenis tindak tutur khususnya pada tindak tutur direktif dimana penutur melakukan suatu upaya agar mitra tutur melakukan sesuatu seperti yang dimaksudnya. Kerbrat-Orecchioni (2008: 20) mendefinisikan tindak tutur direktif merupakan bentuk tuturan yang dimaksudkan penuturnya agar mitra tutur melakukan tindakan yang disebutkan di dalam tuturan itu. Searle (dalam Sumarti, 2014: 243) menyebutkan verba yang termasuk dalam jenis tindak tutur direktif, yaitu: ask 'bertanya', order 'memesan', command 'menyuruh', request 'meminta', beg 'memohon', pray 'berdoa', invite 'mengundang', permit 'meminta izin', dan advise 'menyarankan'.

Tindak tutur direktif kerap ditemukan di dalam lingkungan pekerjaan, misalnya pada saat berkomunikasi dengan rekan kerja, dengan anak buah, dengan atasan atau pimpinan, dan lain sebagainya. Penelitian ini difokuskan pada komunikasi antara pemilik bisnis dengan konsumen / klien dan rekan kerjanya di dalam sebuah bisnis jasa perencanaan acara pernikahan atau biasa disebut dengan Wedding Organizer (WO). Saat ini, bisnis jasa wedding organizer menjadi bisnis yang banyak digeluti tidak hanya di ibu kota tetapi juga di kota-kota kecil maupun kabupaten. Menjamurnya bisnis ini sejalan dengan kebutuhan masyarakat yang 
menginginkan kemudahan dan kepraktisan dalam merencanakan sebuah acara pernikahan. Dengan adanya wedding organizer, maka beban dalam merencanakan sebuah pesta pernikahan menjadi berkurang.

Sebagai bisnis penyedia jasa, kenyamanan dan kepuasan klien dan rekan kerja menjadi sesuatu yang sangat diutamakan agar terjalin hubungan yang baik dan tidak merugikan satu sama lain. Maka dari itu, cara berkomunikasi dan berbahasa si penyedia jasa menjadi hal paling dasar yang dapat menentukan penilaian seseorang terhadap mereka. Dengan kata lain, aturan atau prinsip kesantunan sangat dibutuhkan dalam situasi tutur tersebut khususnya dalam tindak tutur direktif dimana tindakan permintaan atau permohonan harus diungkapkan tanpa menyinggung lawan tutur. Hal ini lah yang menarik penulis untuk melakukan penelitian tentang strategi kesantunan tindak tutur direktif dalam pesan whatsApp yang dikirim oleh pemilik bisnis jasa Wedding Organizer kepada klien atau rekan kerjanya.

\section{METODE PENELITIAN}

Metode yang digunakan dalam penelitian ini adalah metode deskriptif kualitatif dengan pendekatan pragmatis. Menurut (Mukhtar, 2013: 28), penelitian deskriptif kualitatif berusaha mendeskripsikan seluruh gejala atau keadaan yang ada, yaitu keadaan gejala menurut apa adanya pada saat penelitian dilakukan. Sedangkan menurut Moleong (dalam Haula, 2019: 28) penelitian kualitatif adalah penelitian yang bermaksud untuk memahami fenomena tentang apa yang dialami oleh subjek penelitian secara holistik, dan dengan cara deskripsi dalam bentuk kata-kata dan bahasa, pada suatu konteks khusus dan metode yang alamiah. Pendekatan penelitian pragmatis digunakan untuk mengkaji mengenai makna ujaran dalam situasi-situasi tertentu yang mencangkup penggunaan bahasa, komunikasi, konteks, dan penafsiran. Penelitian ini menggunakan teori strategi kesantunan yang dikemukan oleh Brown dan Levinson (1987) sebagai pisau analisis.

Data pada penelitian ini diperoleh dari pesan yang dikirim melalui aplikasi WhatsApp antara pemilik bisnis dengan kliennya di dalam bisnis jasa perencanaan acara pernikahan atau dapat disebut Wedding Organizer (WO). Bisnis jasa tersebut bernama Evodia Wedding Organizer dan terletak di kota Bandung. Pesan yang diteliti dibatasi pada pesan yang mengandung tindak tutur direktif di bulan September dan Oktober tahun 2020. Tahap penelitian yang digunakan dalam penelitian ini ada tiga tahapan yang sesuai dengan pendapat Sudaryanto (2001: 5-7), yaitu: 1) tahap penyediaan data, pada tahap ini metode yang digunakan adalah metode simak dan catat, yaitu dengan membaca dan menyimak pesan-pesan pada sumber data dan kemudian mencatat pesan mana saja yang termasuk ke dalam tindak tutur direktif. Hasilnya, peneliti memperoleh 25 pesan yang termasuk ke dalam tindak tutur direktif; 2) tahap analisis data, pada tahap ini, data dianalisis sesuai dengan masalah yang telah dirumuskan, yakni menentukan dan mengklasifikasikan data berdasarkan teori strategi kesantunan Brown dan Levinson (1987); yang terkahir adalah 3) tahap penyajian hasil analisis, dari 25 data yang telah dianalisis, peneliti menggunakan 6 data yang akan digunakan sebagai sampel pada bagian pembahasan. Metode yang dipakai dalam menyajikan hasil penelitian ini adalah metode formal dan informal. Metode formal adalah penyajian data menggunakan lambang-lambang, dalam hal ini 
peneliti menggunakan tabel. Sedangkan metode informal menurut Sudaryanto (dalam Adhiti, 2017: 36) adalah penyajian hasil analisis dengan untaian kata-kata agar penjelasannya terurai dan terinci.

\section{HASIL DAN PEMBAHASAN}

Berdasarkan hasil penelitian, penulis menemukan 25 pesan yang akan digunakan sebagai data. Data merupakan pesan yang termasuk ke dalam jenis tindak tutur direktif yang kemudian diklasifikasikan berdasarkan strategi kesantunan menurut Brown dan Levinson (1987). Strategi kesantunan tersebut secara rinci dapat dilihat pada tabel di bawah ini:

Tabel 1. Hasil Analisis Data

\begin{tabular}{clc}
\hline No. & \multicolumn{1}{c}{ Strategi Kesantunan } & Jumlah \\
\hline 1 & $\begin{array}{l}\text { Bald-on Record Strategy (Strategi terus terang / } \\
\text { tanpa strategi) }\end{array}$ & 0 \\
2 & $\begin{array}{l}\text { Positive politeness strategy (strategi kesantunan } \\
\text { positif/keakraban) } \\
\text { Negative politeness strategy (strategi kesantunan } \\
\text { negatif/formal) } \\
\text { Off-record politeness strategy (strategi tidak } \\
\text { langsung atau tersamar) }\end{array}$ & 5 \\
\hline
\end{tabular}

Tabel 1 menunjukkan bahwa strategi yang paling banyak digunakan adalah strategi kesantunan positif, diikuti dengan strategi kesantunan negatif dan strategi tidak langsung. Di bawah ini akan dipaparkan penjelasan contoh data dari masingmasing klasifikasi.

\section{Positive Politeness Strategy (Strategi Kesantunan Positif/Keakraban)}

\section{Data 1:}

"Assalamualaikum teh *** kang ****, mumpung lagi weekend nih hehe guidebooknya diisi terus difoto ya, terutama bagian data diri cpp cpw sama daftar list vendor beserta kontaknya. Kalo ada lagi yg belum perintilannya bilang aja ya kang teh, semangaaaat :-6

Tuturan pada data di atas merupakan jenis tindak tutur direktif command 'menyuruh' atau request 'meminta' yaitu penutur bermaksud meminta lawan tutur untuk mengisi data pada sebuah buku (guidebook).

Penutur menggunakan beberapa cara dalam melakukan tindakannya. Pertama, penutur menggunakan penanda keakraban kelompok yang ditunjukkan dengan panggilan "teh" dan "kang" yang berasal dari kata teteh dan akang. Kedua kata 
tersebut merupakan panggilan untuk orang yang lebih tua atau sebagai bentuk menghargai kepada lawan tutur di dalam masyarakat budaya sunda. Kedua, pentur memusatkan perhatiannya kepada lawan tutur yang ditunjukkan dengan tuturan "mumpung lagi weekend nih hehe". Maksud dari tuturan tersebut adalah penutur berharap bahwa tindakan yang dilakukannya tidak akan menganggu lawan tutur karena dilakukan pada saat hari libur atau weekend, dengan kata lain, penutur melihat dan mempertimbangkan terlebih dahulu situasi dan kondisi lawan tutur. Ketiga, penutur menawarkan bantuan kepada lawan tutur dengan menggunakan kalimat "Kalo ada lagi yg belum perintilannya bilang aja ya kang teh". Maksudnya adalah, penutur akan melakukan tindakan lain jika kebutuhan lawan tutur belum terpenuhi. Keempat, penutur memberi perhatian lebih kepada lawan tutur berupa dukungan yang ditunjukkan dengan tuturan "semangaaaat".

Keempat cara tersebut bertujuan untuk menunjukkan keakraban kepada lawan tutur dimana lawan tutur adalah seorang klien yang tidak memiliki hubungan dekat dengan penutur. Penutur berusaha meminimalisasi jarak dengan lawan tutur dengan cara mengungkapkan perhatian agar keinginannya terpenuhi dan dianggap sebagai keinginan bersama antara penutur dengan lawan tutur. Oleh karena itu, strategi yang dilakukan penutur pada data 1 adalah strategi kesantunan positif (positive politeness strategy).

\section{Data 2:}

“Tenang aja vendor2 dari saya mah masih aman kok, kalo corona udah mereda secepatnya aja ya teh kasih tanggal, soalnya vendor2 pasti numpuk job nya. Stay safe aja sekarang mah $\odot$ "

Pada data 2, penutur melakukan tindakan permintaan kepada lawan tutur untuk segera memastikan tanggal pernikahannya jika keadaan sudah membaik, keadaan yang dimaksud adalah situasi pada masa pandemi. Oleh karena itu, tuturan di atas termasuk ke dalam tindak tutur direktif yaitu request 'meminta'.

Cara pertama yang digunakan penutur dalam menyampaikan maksudnya adalah memberikan perhatian lebih dan simpati kepada lawan tutur. Hal ini ditunjukkan oleh frasa "tenang aja" pada tuturan "tenang aja vendor2 dari saya mah masih aman kok", tuturan tersebut digunakan oleh penutur dengan maksud mengurangi kekhawatiran lawan tutur. Tuturan lain yang menunjukkan perhatian kepada lawan tutur adalah "kalo corona udah mereda..." dan "Stay safe aja sekarang mah". Pada tuturannya, penutur tidak memaksa lawan tutur untuk memenuhi permintaannya dan mengingatkan kepada lawan tutur agar mementingkan keselamatannya terlebih dahulu. Cara kedua yang digunakan penutur adalah memberikan alasan tertentu atas permintaannya, hal ini ditunjukkan oleh tuturan "soalnya vendor 2 pasti numpuk job nya". Selain kedua cara tersebut, penutur juga menggunakan penanda keakraban kelompok seperti yang terdapat pada data 1 . Penanda tersebut ditunjukkan oleh penggilan " $t e h$ ".

Cara-cara yang dilakukan penutur bertujuan untuk menghindari konflik dan melancarkan hubungan sosial dengan lawan tutur karena penutur meminimalisasi FTA atau tindakan yang mengancam muka, maka dapat dikatakan bahwa strategi pada tuturan di atas adalah strategi kesantunan positif (positive politeness strategy). 


\section{Negative Politeness Strategy (Strategi Kesantunan Kegatif/Formal)}

\section{Data 3:}

"Assalamualaikum, selamat malam, maaf mengganggu. Perkenalkan saya **** dari evodia weding organizer yang insyaAllah membantu pernikahan ${ }^{* * * *}$ dan **** di villa casa d langit nanti. Mohon maaf sebelumnya atas keterlambatan informasi meeting vendor karena ada sesuatu hal, insyaAllah meeting vendornya akan dilaksanakan tgl 15 November di pabrik badjoe di jalan sukarno hatta pukul 16.00 WIB. Terimakasih"

Tuturan pada data di atas merupakan tindak tutur direktif invite 'mengundang'. Penutur, dalam hal ini adalah pemilik bisnis, mengundang rekan kerjanya untuk menghadiri sebuah pertemuan yang telah ditentukan tempat dan waktunya seperti yang disebutkan oleh penutur.

Penutur menggunakan cara meminta maaf, merendahkan diri, dan menyatakan secara tidak langsung untuk menyampaikan maksud dan tujuannya. Cara meminta maaf dan merendahkan diri ditunjukkan dengan tuturan "maaf mengganggu" dan "mohon maaf sebelumnya atas keterlambatan informasi meeting vendor karena ada sesuatu hal". Penggunaan tuturan tersebut merupakan suatu upaya agar tindakannya tidak mengancam muka negatif lawan tutur sehingga lawan tutur merasa dihargai dan dihormati. Selain itu, penutur merendahkan dirinya dengan mengakui kesalahan atas keterlambatan informasi yang dilakukannya. Tindakan menyatakan secara tidak langsung juga dilakukan oleh penutur dengan cara memberikan informasi tanggal, tempat, dan waktu dilaksanakannya pertemuan dengan maksud agar lawan tutur menghadiri pertemuan tersebut sesuai dengan jadwal yang telah ditentukan.

Melalui cara-cara tersebut, penutur sebagai pemilik bisnis berusaha menghargai dan menghormati rekan kerjanya (lawan tutur) dengan menampilkan fungsi-fungsi penunjang agar tuturannya terasa lebih formal dan tidak memaksa. Dapat disimpulkan bahwa tuturan pada data 3 adalah tuturan yang menggunakan strategi kesantunan negatif (negative politeness strategy).

\section{Data 4:}

"Assalamualaikum, wilujeng siang, punten ngawagel. Nepangkeun abdi **** ti evodia wedding organizer wona teh **** sareng kang **** kanggo event 7 februari di villa hanjuang siang. Punten kang, bade konfirmasi. Dupi pami enjing abdi cek venue tiasa? Haturnuhun sateuacanna"

“Assalamualaikum, selamat siang, maaf mengganggu. Perkenalkan saya **** dari Evodia Wedding Organizer WOnya teh **** dan kang **** untuk acara 7 Februari di Villa Hanjuang Siang. Maaf kang, mau konfirmasi. Kalau seandainya besok pagi saya cek venue bisa? Terimakasih sebelumnya".

Tuturan pada data 4 merupakan tindak tutur direktif permit 'meminta izin'. Pemilik bisnis sebagai penutur bermaksud meminta izin untuk melakukan 
pengecekan lokasi yang disampaikan dengan cara bertanya kepada pemilik Villa Hanjuang Siang.

Untuk melakukan tindakannya, penutur menggunakan beberapa cara yaitu meminta maaf, merendahkan diri, bersikap pesimis, dan mengajukan pertanyaan. Tindakan meminta maaf dan merendahkan diri yang dilakukan penutur ditunjukkan dengan tuturan "punten ngawagel" (maaf mengganggu) dan "punten kang, bade konfirmasi" ("maaf kang, mau konfirmasi"). Hal ini dilakukan penutur dengan maksud menghargai dan menghormati lawan tutur sebagai pemilik Villa yang tidak mempunyai hubungan dekat dengan penutur. Sedangkan sikap pesimis penutur ditunjukkan oleh tuturan "Dupi pami enjing abdi cek venue tiasa?" ("Kalau seandainya besok pagi saya cek venue bisa?") yang disampaikan dengan cara mengajukan pertanyaan. Penggunaan petanyaan dan sikap pesimis tersebut dapat mengurangi ancaman muka negatif lawan tutur, sehingga tindakan penutur yang meminta sesuatu bukanlah sebuah beban bagi lawan tutur.

Cara-cara yang telah disebutkan di atas digunakan oleh penutur karena adanya sebuah asumsi bahwa penutur kemungkinan besar memberikan beban atau gangguan kepada lawan tutur karena telah memasuki daerah lawan tutur. Oleh karena itu, strategi yang dilakukan penutur pada data 4 adalah strategi kesantunan negatif (negative politeness strategy).

\section{Off-record Politeness Strategy (Strategi Tidak Langsung atau Tersamar)}

\section{Data 5:}

"assalamualaikum teh *** dan kang ****

Buat meeting room nanti venue (a.n mba ***) sudah konfirmasi bisa tgl 27 november jam 14.00 wib tempatnya di burangrang room"

Tuturan di atas merupakan tindak tutur direktif request 'meminta' yang disampaikan dengan menggunakan kalimat pernyataan atau kalimat deklaratif. Penutur, dalam hal ini adalah pemilik bisnis, bermaksud untuk meminta kliennya agar menghadiri pertemuan (meeting) yang disampaikan dengan cara memberikan informasi kepada lawan tutur berupa tanggal, waktu, dan tempat akan dilakukannya pertemuan. Penutur berupaya melakukan tindakan dengan meminimalisasi ancaman muka lawan tutur dengan tuturan deklaratif, sehingga lawan tutur tidak merasa diperintah oleh penutur untuk memenuhi keinginannya. Dapat dilihat bahwa strategi yang dilakukan penutur pada data 5 adalah strategi tidak langsung (off-record politeness strategy).

\section{Data 6:}

"Teh ****, besok makanan gak bisa dianter karena orang catering semuanya standby di venue mesjid abri cimahi, jadi harus diambil langsung ke sana".

Pada data 6, pemilik bisnis sebagai penutur melakukan tindakan permintaan kepada lawan tutur yaitu kliennya agar memenuhi keinginan penutur, yaitu mengambil makanan di suatu tempat. Namun, kalimat yang digunakan penutur 
bukan kalimat imperatif melainkan kalimat deklaratif dengan memberikan informasi kepada lawan tutur bahwa petugas catering tidak dapat mengantar makanannya sehingga lawan tutur harus mengambil makanannya. Penutur melakukan tindakannya dengan cara tersamar dan tidak menggambarkan maksud komunikatif yang jelas dan membiarkan lawan tutur menginterpretasikan sendiri tindakannya. Strategi yang digunakan oleh penutur pada data 6 disebut dengan strategi tidak langsung (off-record politeness strategy).

\section{PENUTUP}

Berdasarkan hasil penelitian dapat disimpulkan bahwa strategi kesantunan tindak tutur direktif yang digunakan oleh pemilik bisnis jasa Wedding Organizer dalam berkomunikasi dengan klien atau rekan kerjanya ada tiga strategi, yaitu strategi kesantunan positif, strategi kesantunan negatif, dan strategi tidak langsung. Strategi yang paling banyak ditemukan adalah strategi kesantunan positif sebanyak 15 data, kemudian diikuti oleh strategi kesantunan negatif dan strategi tidak langsung dengan jumlah data yang sama yaitu sebanyak 5 data. Sementara itu, strategi terus terang / tanpa strategi tidak ditemukan pada sumber data.

Sebagai strategi yang paling banyak digunakan, strategi kesantunan positif berfungsi sebagai pelancar hubungan sosial antara pemilik bisnis sebagai penutur dengan klien dan rekan kerjanya sebagai lawan tutur. Pemilik bisnis menunjukkan keakraban dengan rekan kerja dan kliennya serta berusaha meminimalisasi jarak dengan mereka dengan cara mengungkapkan perhatian dan persahabatan. Hal tersebut dilakukan agar klien dan rekan kerjanya tetap merasa nyaman dan percaya dengan perbuatan, layanan, dan servis yang dilakukan oleh bisnis jasa wedding organizer tersebut. Selain itu, penggunaan strategi kesantunan positif dapat menimbulkan hubungan yang harmonis antara penutur dan lawan tutur karena lawan tutur merasa dihargai dan dihormati.

Melalui artikel ini, penulis menyarankan agar setiap orang selalu memperhatikan kesantunan dalam berbahasa, khususnya di dalam lingkungan pekerjaan, karena bahasa menjadi alat yang paling dasar dalam menentukan karakter seseorang atau suatu kelompok. Ketidaksantunan dalam berbahasa akan menimbulkan dampak negatif yang dapat merugikan penutur itu sendiri. Sebagaimana peribahasa dalam bahasa sunda "hade goreng $k u$ basa" yang mengandung makna bahwa baik atau buruknya sesuatu tergantung bagaimana bahasa dan cara kita menuturkannya.

\section{DAFTAR PUSTAKA}

Adani, R., dkk. (2017). Strategi Kesantunan Tuturan Ketidaksetujuan dalam Drama 101st Marriage Proposal. Jurnal Metahumaniora, 7(1), 82 - 90.

Brown, Penelope \& Stephen C. Levinson. (1987). Politeness: Some Universals in Language Usage. Cambridge: Cambridge University Press.

Fraser, B., \& Nolen, W. (1981). The Association of Deference With Linguistic Form. 
International Journal of the Sociology of Language, 27, 93-109.

Haula, B., \& Nur, T. 2019. Konseptualisasi Metafora dalam Rubrik Opini Kompas: Kajian Semantik Kognitif. Retorika: Jurnal Bahasa, Sastra, Dan Pengajarannya, 12(1), 25-35.

Iran Adhiti, I. A. (2017). Pantulan (Refleks) Proto Austronesia (Pan) Ke Protobahasa Kabola, Protobahasa Hamap, Dan Protobahasa Klon Di Pulau Alor, Nusa Tenggara Timur. KULTURISTIK: Jurnal Bahasa Dan Budaya, 1(1), 32. https://doi.org/10.22225/kulturistik.1.1.215

Kerbrat-Orecchioni, C. (2008). Les Actes de Langage dans Le Discours: Theories et Fonctionnement. Paris: Armand Colin.

Leech, G. (1982). Principles of Pragmatics. London and New York: Longman.

Mukhtar. (2013). Metode Penelitian Deskriftif Kualitatif. Jakarta: GP Press Group.

Mulatsih, S. (2014). STRATEGI KESANTUNAN PADA PESAN SINGKAT (SMS) MAHASISWA KE DOSEN. SEMINAR NASIONAL PRASASTI (Pragmatik: Sastra Dan Linguistik), 2, 213-219.

Santoso, W. J. (2005). Bentuk, Faktor, dan Skala Kesantunan dalam Penyampaian Maksud. Jurnal Universitas Negeri Semarang, 46(2) , 113-116.

Sudaryanto. 1993. Metode dan Aneka Teknik Analisis Bahasa (Pengantar Penelitian Wahana Kebudayaan Secara Linguistis). Yogyakarta: Duta Wacana University Press.

Sumarti. (2014). STRATEGI KESANTUNAN POSITIF DALAM TINDAK TUTUR DIREKTIF GURU. SEMINAR NASIONAL PRASASTI (Pragmatik: Sastra Dan Linguistik), 241-248. https://jurnal.uns.ac.id/prosidingprasasti/article/view/446

Syahrin, E. (2008). STRATEGI KESANTUNAN SEBAGAI KOMPETENSI PRAGMATIK DALAM TINDAK TUTUR DIREKTIF BAHASA PRANCIS. Jurnal Universitas Medan, NO 69TH XX, 7-8. 